\title{
Application of Advanced Reservoir Characterization, Simulation, and Production Optimization Strategies to Maximize Recovery in Slope and Basin Clastic Reservoirs, West Texas (Delaware Basin)
}

\author{
Quarterly Report \\ April 1 - June 30, 1997 \\ By:
Shirley P. Dutton
}

Work Performed Under Contract No.: DE-FC22-95BC14936

For

U.S. Department of Energy

Office of Fossil Energy

Federal Energy Technology Center

P.O. Box 880

Morgantown, West Virginia 26507-0880

By

Bureau of Economic Geology

The University of Texas at Austin

University Station, Box X

Austin, Texas 78713-7508 


\section{Disclaimer}

This report was prepared as an account of work sponsored by an agency of the United States Government. Neither the United States Government nor any agency thereof, nor any of their employees, makes any warranty, express or implied, or assumes any legal liability or responsibility for the accuracy, completeness, or usefulness of any information, apparatus, product, or process disclosed, or represents that its use would not infringe privately owned rights. Reference herein to any specific commercial product, process, or service by trade

name, trademark, manufacturer, or otherwise does not necessarily constitute or imply its endorsement, recommendation, or favoring by the United States Government or any agency thereof. The views and opinions of authors expressed herein do not necessarily state or reflect those of the United States Government or any agency thereof. 


\section{TECHNICAL PROGRESS REPORT}

Title:

Cooperative Agreement No.:

Institution:

Date of Report:

Award Date:

Anticipated Completion Date for this Budget:

Government Award for this Budget Period:

Program Manager:

Principal Investigator:

Contracting Officer's Representative:

Reporting Period:
APPLICATION OF ADVANCED RESERVOIR

CHARACTERIZATION, SIMULATION, AND PRODUCTION OPTIMIZATION STRATEGIES TO MAXIMIZE RECOVERY IN SLOPE AND BASIN CLASTIC RESERVOIRS, WEST TEXAS (DELAWARE BASIN)

DE-FC22-95BC14936--11

Bureau of Economic Geology

The University of Texas at Austin University Station, Box $X$

Austin, Texas 78713-7508

J uly 30, 1997

March 31, 1995

December 31, 1997

$\$ 1,010,208$

J erry Casteel

Shirley P. Dutton

J erry Casteel

April 1, 1997 - J une 30, 1997 


\section{OBJ ECTIVES}

The objective of this project is to demonstrate that detailed reservoir characterization of slope and basin clastic reservoirs in sandstones of the Delaware Mountain Group in the Delaware Basin of West Texas and New Mexico is a cost effective way to recover a higher percentage of the original oil in place through strategic placement of infill wells and geologically based field development. Project objectives are divided into two major phases. The objectives of the reservoir characterization phase of the project are to provide a detailed understanding of the architecture and heterogeneity of two fields, the Ford Geraldine unit and Ford West field, which produce from the Bell Canyon and Cherry Canyon Formations, respectively, of the Delaware Mountain Group and to compare Bell Canyon and Cherry Canyon reservoirs. Reservoir characterization will utilize 3-D seismic data, high-resolution sequence stratigraphy, subsurface field studies, outcrop characterization, and other techniques. Once the reservoircharacterization study of both fields is completed, a pilot area of approximately $1 \mathrm{mi}^{2}$ in one of the fields will be chosen for reservoir simulation.

The objectives of the implementation phase of the project are to (1) apply the knowledge gained from reservoir characterization and simulation studies to increase recovery from the pilot area, (2) demonstrate that economically significant unrecovered oil remains in geologically resolvable untapped compartments, and (3) test the accuracy of reservoir characterization and flow simulation as predictive tools in resource preservation of mature fields. A geologically designed, enhanced-recovery program ( $\mathrm{CO}_{2}$ flood, waterflood, or polymer flood) and wellcompletion program will be developed, and one to three infill wells will be drilled and cored. Through technology transfer workshops and other presentations, the knowledge gained in the comparative study of these two fields can then be applied to increase production from the more than 100 other Delaware Mountain Group reservoirs. 


\section{SUMMARY OF TECHNICAL PROGRESS}

\section{Geophysical Characterization}

Interpretation of the 3-D seismic survey that was shot for this project was summarized in the draft annual report (Dutton and others, 1997). The 3-D seismic volume indicates that Ramsey sandstone thickness in Ford Geraldine unit is $\leq 1 / 4$ wavelength of the seismic data. The coherency cube is effective in delineating the field outline, and a residual map of the top of the Lamar Limestone identified a residual high that is associated with Ramsey sandstone thickness. The amplitude family of attributes had the highest correlations with the reservoir properties, especially porosity. The best correlation coefficients were less than 0.4 when all the wells were used, but higher correlations were found in smaller areas within the unit.

\section{Reservoir Characterization}

The Ramsey sandstone was subdivided into the upper Ramsey 2 and lower Ramsey 1 sandstones for petrophysical characterization of each unit separately. A complete set of maps for the Ramsey 1 and Ramsey 2 sandstones was produced, as follows: average porosity, porosity $\mathrm{x}$ thickness $\left(\mathrm{S}_{\mathrm{W}}\right)$, geometric average permeability, permeability $\mathrm{x}$ thickness, average water saturation, average residual-oil saturation, average mobile-oil saturation, porous hydrocarbon volume $\left(\mathrm{S}_{\mathrm{O}} \times \mathrm{phi} \times \mathrm{h}\right.$ ), and net pay (for phi $>15 \%$ and $20 \%$ ). For wells that lacked a porosity log but had core-analysis data, core-porosity data were used to calculate average porosity and porosity $\mathrm{x}$ thickness. 
The method used to calculate water saturation for the entire Ramsey sandstone was deemed the best method to calculate $S_{W}$ for the Ramsey 1 interval. In this method, average bulk volume water (BVW) values were extrapolated to the northeast from the rest of the field where resistivity logs are available, and BVW values were assigned to wells with porosity logs. Water saturations $\left(S_{w}\right)$ were calculated in these wells by the formula $S_{w}=B V W a v g / \varnothing$, then these $S_{w}$ values were averaged and mapped. Using this method, BVW and $\mathrm{S}_{\mathrm{W}}$ maps of the total Ramsey and Ramsey 1 both show an increase to the northeast, which is to be expected because that direction is down structural dip.

This method may not correctly estimate $S_{W}$ in the Ramsey 2 interval because it is structurally higher than the Ramsey 1. To make the Ramsey 2 maps, core-derived water-saturation data were used for the Ramsey 2 sandstone to map bulk volume water and construct the $\mathrm{S}_{\mathrm{W}}$ and other derivative maps. By separating Ramsey 1 and 2, a more accurate assessment of total net pay is possible in the structurally downdip northeastern part of the field.

\section{Outcrop Characterization}

The geometry and lateral continuity of important architectural elements for Bell Canyon sandstones were documented and a depositional model was developed and presented in the draft annual report. The report illustrates key stratigraphic relationships in photomosaics and bedding diagrams from Bell Canyon outcrops. Stratal relationships indicate that upper Bell Canyon sandstones exposed in outcrop were deposited by high- and low-density turbidity currents in a basinal deep-water setting. The fundamental depositional element is the channel with attached levees and lobes. The depositional model developed from outcrop for this project can be widely applied by operators to other reservoirs that produce from Delaware Mountain Group sandstones. 


\section{Producibility Problem Characterization Recovery Technology Identification and Analysis}

Simulations of Tertiary Recovery.-To estimate the tertiary recovery potential of the demonstration area in the northern part of the Ford Geraldine Unit (FGU), flow simulations were performed for a $\mathrm{CO}_{2}$ flood. A quarter of a five-spot injection pattern in the demonstration area was selected for flow simulations, and two cases of permeability distribution were considered. In the first case, stochastic permeabilities generated by conditional simulation (Dutton and others, 1997) were used. The simulation grid for this case was $6 \times 5 \times 8(x, y$, and $z$ directions, respectively). The second case has layered permeabilities with a $6 \times 5 \times 6$ grid. The block size was $150 \mathrm{ft}$ in the areal ( $x$ and $y)$ directions in both cases. In the vertical $(z)$ direction, the block size was $4 \mathrm{ft}$ for the stochastic case and $5.33 \mathrm{ft}$ for the layered case. In the simulation area, both Ramsey 1 and 2 units are present with an average total thickness of 40 feet. To exclude the intermediate silt unit and other smaller shales and silt streaks, total thickness of productive sandstone was assumed to be $32 \mathrm{ft}$. The stochastic permeabilities were scaled-up to reduce the number of blocks in the $z$ direction from 40 to 8 . A permeability cutoff of 5 md was used to exclude the non-producing zones. Maximum permeability was limited to $200 \mathrm{md}$.

Flow simulations were performed using UTCOMP, an isothermal, three-dimensional, compositional simulator for miscible gas flooding developed at the Department of Petroleum Engineering at The University of Texas at Austin (Chang, 1990). The solution scheme is analogous to IMPES (Implicit Pressure, Explicit Saturations). The equation of state (EOS) is used for flash calculations, phase identification, and fluid property calculations. We have performed three-phase simulations for $\mathrm{C}_{2}$ flood. 
Post-waterflood oil saturations in the demonstration area are estimated from 35 to $39 \%$. An average oil saturation of $37 \%$ was used for these simulations. An exponential relative permeability model for water, oil, and gas flow was fitted to the measured relative permeability data.

In these simulations, five hydrocarbon components were used. Reservoir hydrocarbons were characterized as four pseudocomponents (Khan, 1992), and their properties were calculated from the PVT (pressure, volume, temperature) data provided by CONOCO. The fifth component is $\mathrm{CO}_{2}$. Injection pressure is limited to 2000 psia, and production wells have a flowing bottomhole pressure of 600 psia.

Simulation Results.-Figure 1 is a plot of oil recovery (fraction of OIP) as a function of time for the two cases. This figure shows breakthrough oil recovery of $28 \%$ for stochastic permeabilities and $10 \%$ for layered permeabilities. Unlike a waterflood, these simulations indicate that $\mathrm{CO}_{2}$ injection results in a gradual increase in recovery even after breakthrough in both cases. Ultimate recovery can exceed 38\% of OIP. Oil production rates are shown in Fig. 2. This figure shows a gradual increase in the oil rate until breakthrough. At the time of breakthrough, the oil rate sharply rises to its peak value and gradually declines thereafter. Water-oil ratio (WOR) and gas-oil ratio (GOR) are shown in figures 3 and 4, respectively. These figures show that WOR gradually decreases with the progress of the flood and remains low even after breakthrough but GOR increases sharply after breakthrough. Although the oil rates are quite high for some time after breakthrough (Fig. 2), the limiting factor in a $\mathrm{CO}_{2}$ flood may be the excessive gas production.

Depending on various cut-off criteria, estimates of original oil in place (OOIP) in the demonstration area vary from 12.9 to 18.67 MMSTB (million stock tank barrels) (Soni, 
1987). Approximately 2.83 MMSTB of oil has been produced through primary depletion and secondary waterflood in this area. Based on the most conservative estimate of OOIP of 12.9 MMSTB, post-waterflood OIP in the demonstration area is in excess of 10 MMSTB. Results of the simulations indicate that a minimum of $10 \%$ of the remaining OIP ( 1.0 MMSTB) is recoverable through $\mathrm{CO}_{2}$ flood. This more conservative estimate is based on the breakthrough recovery of a layered model. The stochastic permeability model shows a breakthrough recovery of more than twice this estimate. If the increased gas production after breakthrough can be handled economically, ultimate $\mathrm{CO}_{2}$ flood recovery can exceed $30 \%$ of remaining OIP.

Because the reservoir simulations were not completed by the end of the quarter, a no-cost extension to the project was requested and granted by DOE to December 31,1997 . The results of these simulation will be used by Conoco, the Bureau of Economic Geology, and DOE to determine the feasibility of moving to Phase II, the demonstration phase. 


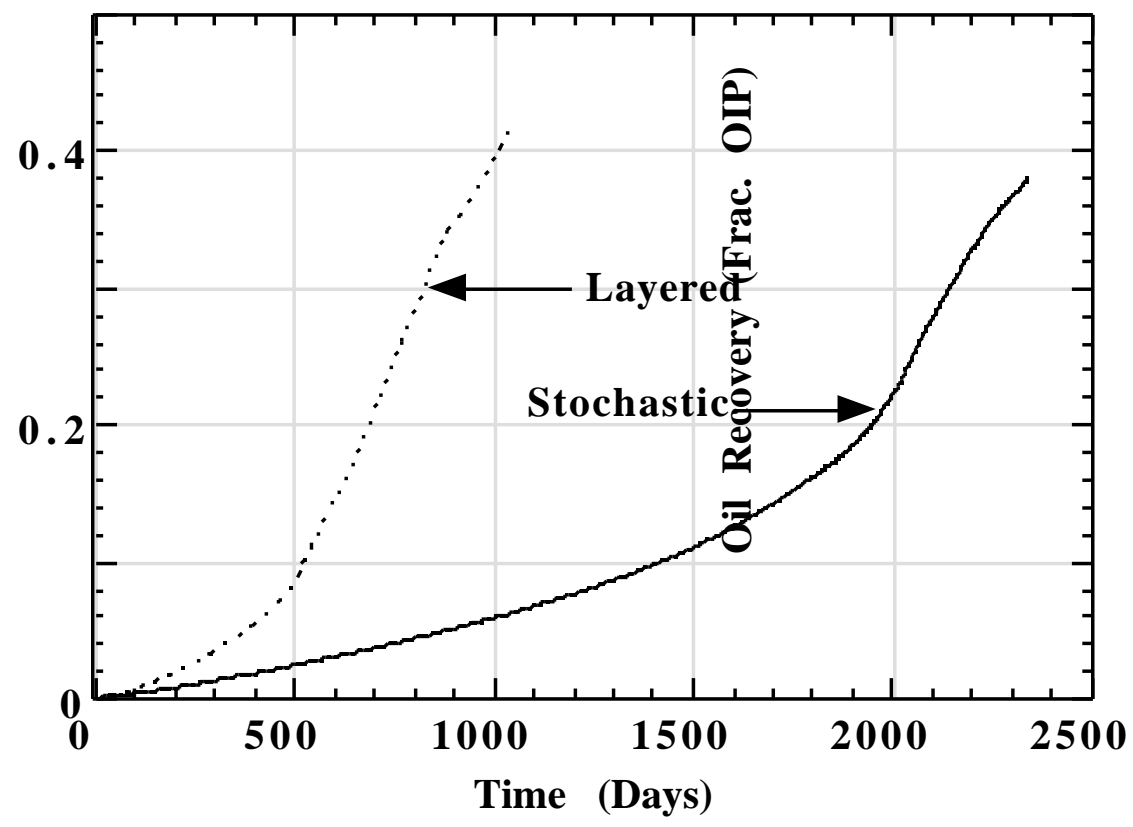

Figure 1. Oil recovery as fraction of remaining oil in place.

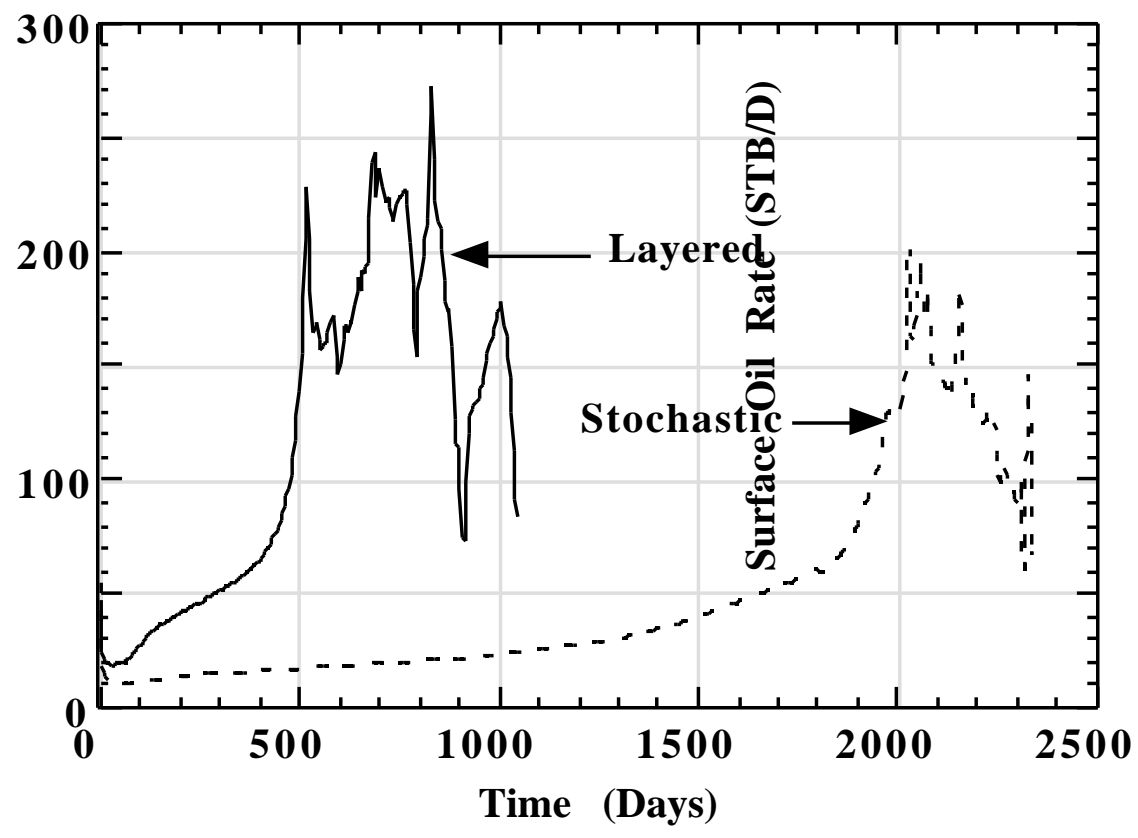

Figure 2. Surface oil production rate. 


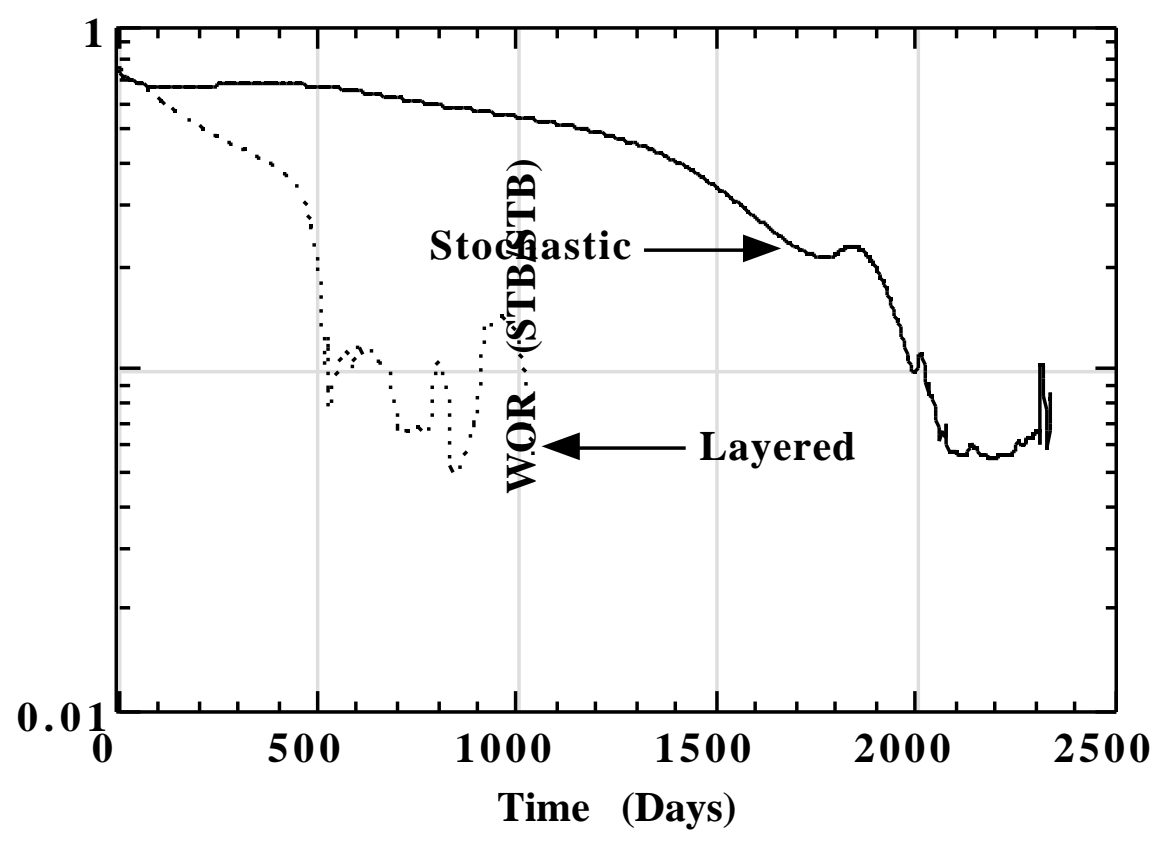

Figure 3. Surface water oil ratio (WOR).

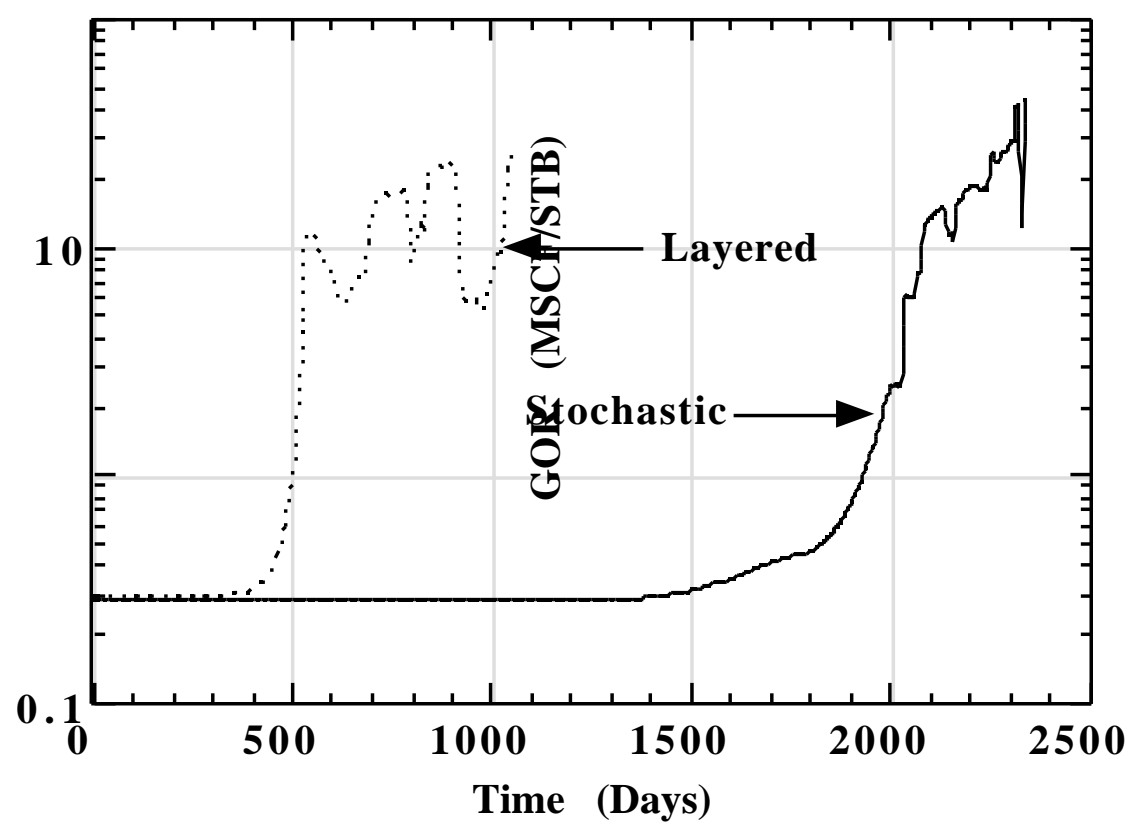

Figure 4. Surface gas oil ratio (GOR). 


\section{Technology Transfer}

The draft annual report for the second year of the project (Dutton and others, 1997) was submitted for review. Upon receiving review comments, the report will be revised and the final report submitted.

Five presentations based on the project were given this quarter, as follows:

Barton, M. D., 1997, Basin floor fan and channel-levee complexes, Permian Bell Canyon Formation (abs.): 1997 AAPG Annual Convention, Official Program, v.

6, Dallas, Texas, p. A9. Poster presentation given by M. D. Barton at the 1997 Annual Meeting of the American Association of Petroleum Geologists in Dallas, Texas, April 7, 1997.

Cole, A. G., Dutton, S. P., Barton, M. D., Hovorka, S. D., Asquith, G. B., 1997, Geophysical characterization of Permian deep-water sandstones, Bell Canyon Formation and Cherry Canyon Formation, Ford Geraldine area, West Texas (Delaware Basin) (abs.): 1997 AAPG Annual Convention, Official Program, v. 6, Dallas, Texas, p. A21. Poster presentation given by A. G. Cole at the 1997 Annual Meeting of the American Association of Petroleum Geologists in Dallas, Texas, April 9, 1997.

Dutton, S. P., Barton, M. D., Hovorka, S. D., Cole, A. G., Asquith, G. B., 1997, Reservoir characterization of Permian deep-water Ramsey Sandstones, Bell Canyon Formation, Ford Geraldine Unit, West Texas (Delaware Basin) (abs.): 1997 AAPG Annual Convention, Official Program, v. 6, Dallas, Texas, p. A31. 
Poster presentation given by S. P. Dutton and G. B. Asquith at the 1997 Annual Meeting of the American Association of Petroleum Geologists in Dallas, Texas, April 9, 1997.

“Application of advanced reservoir characterization, simulation, and production optimization strategies to maximize recovery in slope and basin clastic reservoirs, West Texas (Delaware Basin)," talk presented by M. D. Barton at the DOE Project Review Meeting, Houston, Texas, J une 17, 1997.

Malik, M. A., 1997, A practical approach to scaling-up permeability and relative permeabilities in heterogeneous permeable media: Society of Petroleum Engineers, Proceedings, 1997 SPE Western Regional Meeting, Paper 38310, p. 485-500. Oral presentation given by M. A. Malik in Long Beach, California, J une 26, 1997.

The following four abstracts have been accepted for presentation at the Fall Symposium of the West Texas Geological Society in Midland, Texas on October 30-31, 1997.

Dutton, S. P., Barton, M. D., Clift, S. J., Guzman, J. I., and Cole, A. G., Depositional history of Ramsey Sandstone channel-levee and lobe deposits, Bell Canyon Formation, Ford Geraldine Unit, West Texas (Delaware Basin).

Dutton, S. P., Barton, M. D., Clift, S. J., Guzman, J. I., Asquith, G. B., and Cole, A. G., Application of advanced reservoir characterization to Ramsey Sandstone reservoirs, Ford Geraldine Unit, West Texas (Delaware Basin). 


\begin{abstract}
Asquith, G. B., Dutton, S. P., and Cole, A. G., Delaware effect and the Ramsey Sandstone, Ford Geraldine Unit, Reeves and Culberson Counties, Texas.
Asquith, G. B., Dutton, S. P., Cole, A. G., Razi, M., and Guzman, J. I., Petrophysics of the Ramsey Sandstone, Ford Geraldine Unit, Reeves and Culberson Counties, Texas.

\title{
PLANNED ACTIVITIES
}

Work in the upcoming quarter will focus on completing the simulation of a $\mathrm{CO}_{2}$ flood in the proposed demonstration area and presenting the results to Conoco for their economic analysis. On the basis of the economic analysis, Conoco and the Bureau of Economic Geology will decide whether or not to apply to DOE to begin Phase 2 of the project.

\section{REFERENCES}

Chang, Yih-Bor, Development and application of an equation of state compositional simulator, Ph.D. dissertation, The University of Texas at Austin, 1990.

Dutton, S. P., Asquith, G. B., Barton, M. D., Cole, A. G., Gogas, J., Malik, M. A., Clift, S. J., and Guzman, J. I., 1997, Application of advanced reservoir characterization, simulation, and production optimization strategies to maximize recovery in slope and basin clastic reservoirs, West Texas (Delaware Basin): The University of Texas at Austin, Bureau of Economic Geology, draft annual report prepared for the U.S. Department of Energy, 187 p. 
Khan, S. A., An expert system to aid in compositional simulation of miscible gas flooding," Ph.D. dissertation, The University of Texas at Austin, 1992.

Soni, Yogi, Revised reservoir description for the Ford Geraldine Unit, Culberson and Reeves Counties, Texas, CONOCO Inc. internal technical service report No. 73-87102-1-38, March 1987. 